\title{
Rumah Literasi Rasau Jaya untuk Meningkatkan Cinta Budaya Kearifan Lokal
}

\author{
Dessy Setyowati, Dedek Kurniawati, Exnasia Retno Palupi Handayani \\ Universitas Nahdlatul Ulama Kalimantan Barat \\ E-mail : dessysetyowati@unukalbar.ac.id
}

DOI: https://doi.org/10.21107/pangabdhi.v6i1.6933

Naskah diterima 10 Maret 2020, Revisi 5 April 2020, Terbit 19 April 2020

\begin{abstract}
Abstrak
Rasau Jasa merupakan satu diantara wilayah di Kabupaten Kubu Raya. Penyelenggaraan pendidikan di Kubu Raya khususnya Rasau Jaya yang terlaksana sama dengan di sekolah-sekolah lainnya. Akan tetapi dalam pelayanan pendidikan belum berjalan dengan maksimal. Upaya perbaikan dan pelayanan pada bidang pendidikan terus dilaksanakan. Permasalahan dalam bidang pendidikan yang terjadi di lapangan yaitu keterbatasan buku sebagai sumber baca, kurangnya penggiat di bidang literasi, khususnya di Desa Rasau Jaya Satu, kurangnya kesadaran minat baca dan menulis masyarakat terutama anak-anak, dan kecenderungan masyarakat Rasau Jaya Satu terutama anak-anak pada gawai daripada aktifitas membaca dan menulis. Solusi secara umum pada permasalahan tersebut adalah mengaktifkan kembali rumah pintar sebagai pusat literasi Rasau Jaya. Selain itu, solusi secara khusus dari permasalahan tersebut adalah tersedianya buku-buku terutama yang bermuatan kearifan lokal sebagai sumber baca, terbentuknya tim relawan desa yang mengelola rumah pintar tersebut, masyarakat khususnya anakanak memahami tentang cara membaca dan menulis yang benar, dan masyarakat khususnya anak-anak mampu membuat tulisan berupa cerita pendek ataupun puisi. Luaran kegiatan PKM untuk pihak mitra yaitu berlangsungnya rumah pintar, adanya tim relawan desa, ketersediaan buku bacaan, kemampuan membaca dan menulis meningkat pada masyarakat khususnya anak-anak, dan keterlibatan masyarakat khususnya anak-anak dalam perlombaan mengenai menulis.
\end{abstract}

Kata Kunci : rumah literasi, kearifan lokal, membaca, menulis

\section{PENDAHULUAN}

Kabupaten Kubu Raya memiliki luas wilayah keseluruhan kurang lebih $6.958,22 \mathrm{Km}^{2}$. Satu diantara wilayah dari Kubu Raya adalah kecamatan Rasau Jaya. Penyelenggaraan pendidikan menjadi satu diantara kewajiban dan kewenangan pemerintah daerah Kubu Raya. Penyelenggaraan pendidikan di Kubu Raya khususnya Rasau Jaya yang terlaksana di Rasau Jaya sama dengan di sekolah-sekolah lainnya. Akan tetapi dalam pelayanan pendidikan belum berjalan dengan maksimal. Upaya perbaikan dan pelayanan pada bidang pendidikan terus dilaksanakan. Masalah yang timbul pada bidang pendidikan di Rasau Jaya Satu ini yaitu banyaknya masyarakat khususnya anak-anak yang enggan untuk membaca. Padahal dengan membaca, mereka dapat menambah wawasan dan pengetahuan.

Dewasa ini minat baca anak-anak hingga dewasa tergolong rendah. Hal tersebut berdampak pula pada budaya yang semakin terkikis dan tersingkirkan oleh zaman. Kalangan anak hingga dewasa kini terlalu sering dimanjakan dengan sesuatu yang berbau teknologi. Sebagian besar masyarakat memanfaatkan teknologi bukan untuk menambah wawasan dengan membaca, melainkan aktif untuk mengunduh aplikasi yang di dalamnya berisi konten permainan dan media sosial yang menambah pertemanan. Tanpa disadari aplikasi tersebut telah membius dan menghabiskan waktu mereka untuk bersosialisasi secara nyata dan membuka wawasan tentang dunia secara umum dan mengenal budaya daerah mereka sendiri secara khusus. Aplikasi permainan yang berasal dari dalam maupun luar negeri itu sengaja diciptakan tidak hanya dapat menghibur tapi di sisi lain juga dapat meracuni penerus bangsa.

Pasalnya, mereka lebih hafal nama, tempat, lokasi dan tata cara permainan (games) yang ditawarkan pada sajian penghibur tersebut daripada mengenal tentang budaya mereka sendiri. Ditambah lagi dengan minimnya dukungan dari penggerak pendidikan untuk membiasakan budaya membaca dan menulis 
membuat anak-anak usia sekolah enggan memanfaatkan fasilitas yang sudah tersedia yaitu Rumah Pintar di Desa Rasau Jaya Satu. Rumah Pintar yang telah berdiri pada tahun 2015 belum dimanfaatkan oleh warga Desa Rasau Jaya Satu. Rumah Pintar yang ada terkesan tidak terawat dengan baik dan kekurangan koleksi sumber baca. Adapun dokumentasi sebagai berikut.

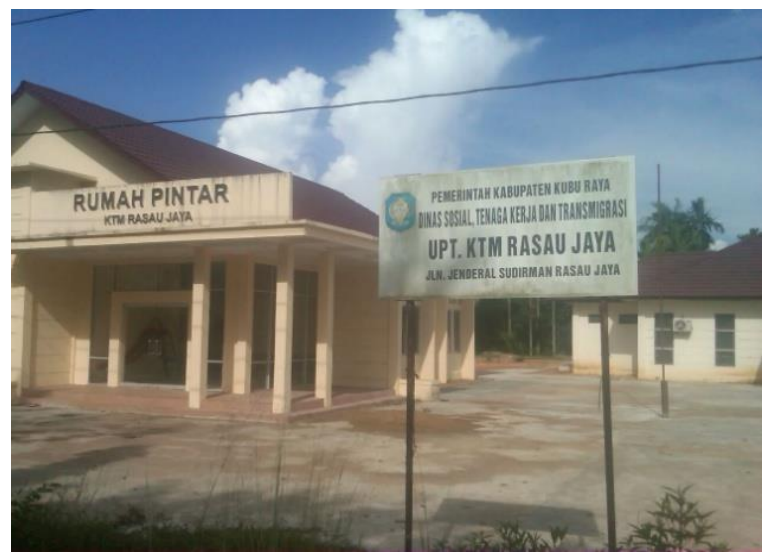

Gambar 1. Lokasi Pelatihan Pustakawan di Aula Kantor Kecamatan Rasau Jaya

Berdasarkan media massa daring borneoonetv.com yang mengungkapkan bahwa anggaran pembangunan rumah pintar yang menelan biaya hingga miliaran rupiah, tidak difungsikan. Padahal manfaatnya akan sangat berguna untuk masyarakat, yaitu menambah wawasan dan pengetahuan. Selain itu, hasil wawancara kepada Sekretaris Desa Rasau Jaya Satu pada 22 Oktober 2018 bahwasanya adanya rumah pintar, akan tetapi kurang mendapat perhatian mengenai keberlangsungannya dan sering tutup atau tidak melayani pengunjung. Hal tersebut menjadi perhatian khusus, sebab jika terus dibiarkan maka budaya literasi yang baik bagi penerus bangsa akan memudar. Rumah

Alternatif solusi tersebut menyikapi hal di atas, yaitu menginisiasi rumah pintar sebagai pusat literasi sebagai wujud upaya menyadarkan pentingnya budaya literasi untuk melestarikan kearifan lokal. Rumah Literasi yang di dalamnya berisi buku/referensi terkait pengetahuan kearifan lokal sebagai koleksi utama dirasa perlu untuk mendukung terwujudnya desa yang melek aksara, cinta literasi serta melestarikan kearifan lokal. Adapun lokasi PKM ini berada di Rumah Pintar Rasau Jaya, Jalan Jendral Sudirman, Desa Rasau Jaya Satu, Kecamatan Rasau Jaya, Kabupaten Kubu Raya.

Berdasarkan uraian diatas, maka permasalahan dari mitra sebagai berikut:
1. Keterbatasan buku sebagai sumber baca.

2. Kurangnya penggiat dibidang literasi di Desa Rasau Jaya Satu.

3. Kurangnya kesadaran minat baca dan menulis.

4. Kecenderungan masyarakat Rasau Jaya Satu, terutama anak-anak pada gawai, daripada aktifitas membaca dan menulis.

\section{METODE}

Program ini dirancang untuk mengeksplorasi minat membaca masyarakat di Desa Rasau Jaya Satu, terutama bagi pemuda dan anak - anak usia sekolah. Dari hasil mengidentifikansi permasalahan yang ada di Desa Rasau Jaya Satu, tim pengusul menggunakan metode pelaksanaan yaitu tahap persiapan, tahap input, tahap proses, dan tahap output. Pada tahap persiapan, pengusul melakukan survei lokasi tempat tujuan PKM, yaitu di Desa Rasau Jaya Satu, Kecamatan Rasau Jaya, Kabupaten Kubu Raya, Kalimantan Barat.

Setelah melakukan survei, pengusul menentukan tujuan dari kegiatan PKM, yaitu untuk meningkatkan budaya literasi kearifan lokal di desa Rasau Jaya Satu dengan menumbuhkan minat baca dan tulis sejak dini, terutama bagi anak - anak usia sekolah. Pada tahap input ada beberapa kegiatan yang akan dilaksanakan, yaitu melakukan survei di lapangan dan mengumpulkan data-data utama yang akan diidentifikasi sehingga ditemukan adanya kendala yang dialami oleh mitra, serta merumuskan masalah dan merancang solusi yang tepat untuk menyelesaikan masalah yang ada.

Pada tahap proses akan ada beberapa hal yang dilakukan, yaitu: Pengumpulan buku, Pendataan, Sosialisasi, Pelatihan dan Pendampingan. Tahap output kegiatan ini ada dua yaitu keluaran dari pengusul dan keluaran dari desa mitra. Target luaran yang direncanakan untuk desa mitra yaitu Rumah Pintar bermanfaat sebagaimana mestinya, adanya tim relawan desa, minat membaca dan menulis miningkat pada masyarakat khususnya anak-anak, dan keterlibatan masyarakat khususnya anak-anak dalam perlombaan mengenai literasi

\section{HASIL DAN PEMBAHASAN}

Pelaksanaan program kemitraan masyarakat di mulai pada Kamis, 28 Februari 2019. Program kemitraan masyarakat yang di danai oleh Kemenristek Dikti dengan judul "Rumah Literasi Rasau Jaya untuk Meningkatkan Cinta Budaya Kearifan Lokal". Rumah literasi merupakan sebutan dari pusat literasi yang dilaksanakan di 
Rumah Pintar. Rumah Pintar yang awalnya tidak dimanfaatkan oleh masyarakat Rasau Jaya, mulai dikelola dan dapat dimanfaatkan oleh masyarakat. Rumah Pintar ini merupakan satu diantara fasilitas Kota Terpadu Mandiri (KTM) yang dikelola oleh Dinas Sosial, Tenaga Kerja, dan Transmigrasi Kabupaten Kubu Raya. Sejak tahun 2015, pembangunan gedung rumah pintar yang telah dibangun dengan bagus belum dimanfaatkan oleh masyarakat khususnya masyarakat Rasau Jaya Satu. Bahkan pengelolaan rumah pintar juga belum begitu jelas. Oleh karena itu, kami melaksanakan kegiatan kemitraan masyarakat berpusat di Rumah Pintar. Sesuai tahapan pelaksanaan PKM sebagai berikut.

\section{a. Tahap Persiapan}

Pada tahap persiapan, pengusul melakukan survei lokasi tempat tujuan PKM, yaitu di Desa Rasau Jaya Satu, Kecamatan Rasau Jaya, Kabupaten Kubu Raya, Kalimantan Barat. Survei lokasi tepatnya di Rumah Pintar Rasau Jaya. Adapun dokumentasi survei lapangan sebagai berikut.

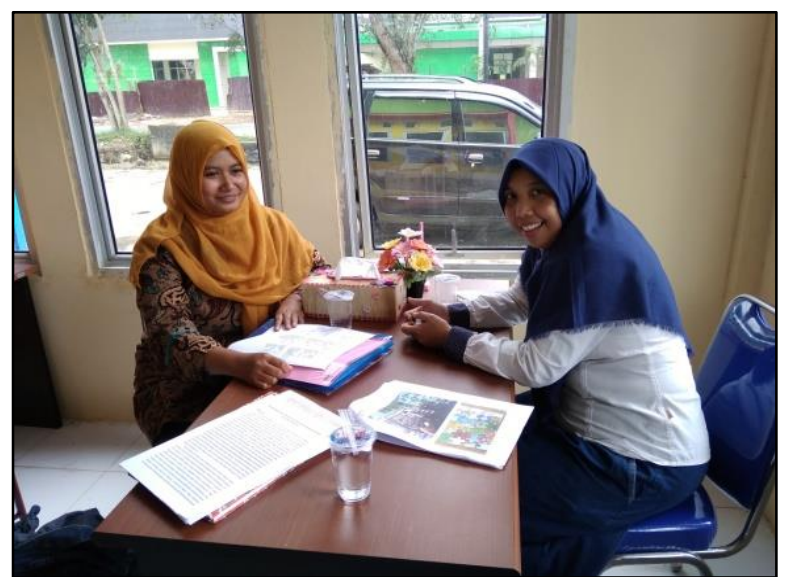

Gambar 2. Orientasi Lapangan di Rumah Pintar Rasau Jaya

\section{b. Tahap Input}

Pada tahap input ada beberapa kegiatan yang akan dilaksanakan, yaitu melakukan survei di lapangan dan mengumpulkan data-data utama yang akan diidentifikasi sehingga ditemukan adanya kendala yang dialami oleh mitra, serta merumuskan masalah dan merancang solusi yang tepat untuk menyelesaikan masalah yang ada. Permasalahan yang ada yaitu keterbatasan buku, kurangnya penggiat di bidang literasi, kurangnya kesadaran minat baca dan menulis, ketergantungan anak-anak dengan gadget. Solusi dari permasalahan tersebut yaitu pengadaan buku dan donator buku, pembentukan relawan desa, pelatihan, serta penyaluran bakat.

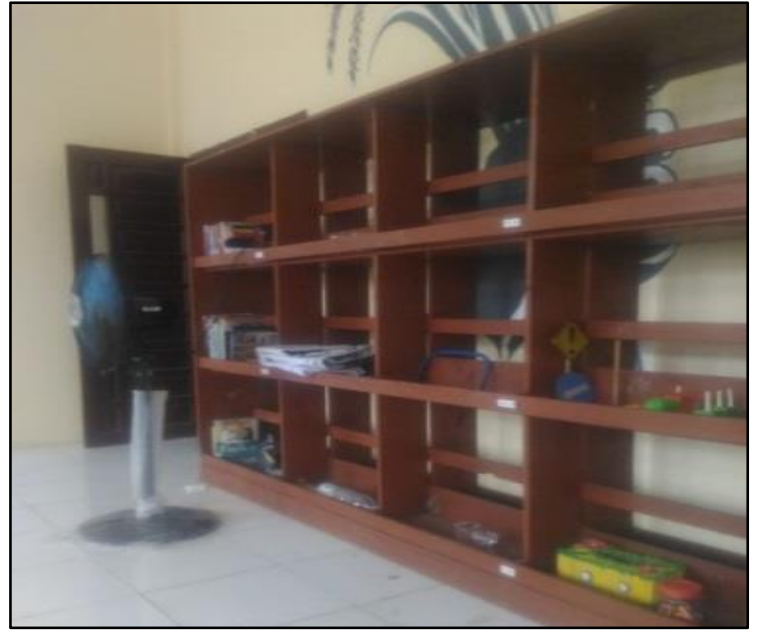

Gambar 3. Pelatihan Pustakawan di Aula Kantor Kecamatan Rasau Jaya

\section{c. Tahap Proses}

Pada tahap proses diadakan berbagai kegiatan antara lain.

\section{Kegiatan Sosialisasi}

Kegiatan sosialisasi pelaksanaan kemitraan masyarakat dilaksanakan pada 3 April 2019 di Kantor Kecamatan. Pelaksanaan sosialisasi dihadiri oleh bapak Camat Rasau Jaya, karang taruna, dan masyarakat Rasau Jaya. Kegiatan sosialisasi dihadiri 27 orang. Semua masyarakat menerima dengan baik kegiatan PKM dari Universitas Nahdlatul Ulama Kalimantan Barat. Dari kegiatan sosialisasi ini adapun terbentuk relawan desa yang membantu pengelolaan Rumah Pintar. Selain itu, pembentukan relawan desa juga sebagai penggerak masyarakat dalam menumbuhkan budaya literasi di Desa Rasau Jaya Satu. Relawan desa yang bersedia membantu pengelolaan rumah pintar sebagai pusat literasi ini berjumlah 2 orang.

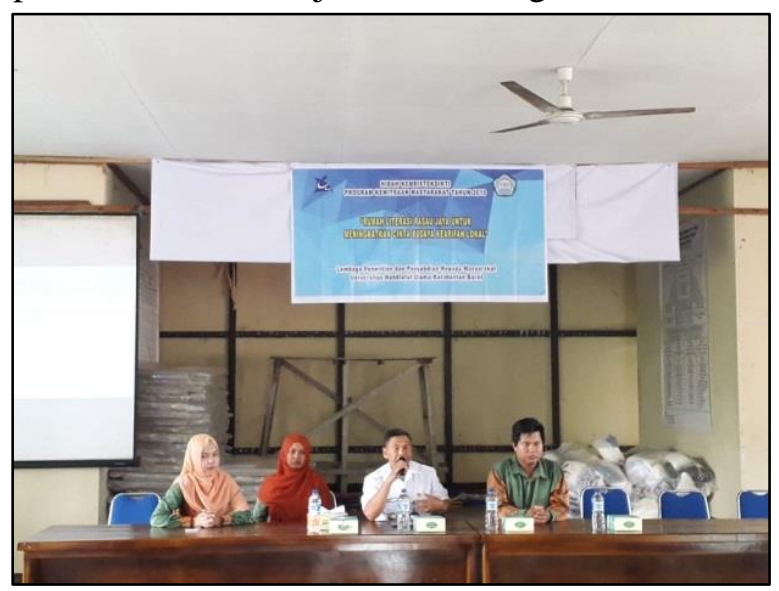

Gambar 4. Sosialisasi kegiatan PKM di Aula Kantor Kecamatan Rasau Jaya 


\section{Kegiatan Pelatihan Pustakawan}

Kegiatan lanjutan adalah pelatihan pustakawan yang diadakan pada 10 April 2019. Kegiatan ini dihadiri oleh relawan desa, pengelola rumah pintar, bahkan pustakawan dari sekolah-sekolah di Rasau Jaya. Pemateri dari pelatihan pustakawan ini merupakan ahli pustakawan dari Dinas Kearsipan dan Perpustakaan Daerah Kubu Raya yaitu Nur Zuhrufi, S.Hum. Pemateri memaparkan mengenai pengelolaan secara administrasi perpustakaan. Tujuan pelaksanaan pelatihan pustakawan ini untuk memberikan wawasan dalam pengelolaan rumah pintar terutama dalam pengelolaan dan penyusunan buku di Rumah Pintar, sehingga rumah pintar ini dapat berjalan semestinya dan sebagai pusat literasi di Rasau Jaya. Peserta yang mengikuti pelatihan pustakawan ini berjumlah 24 orang.

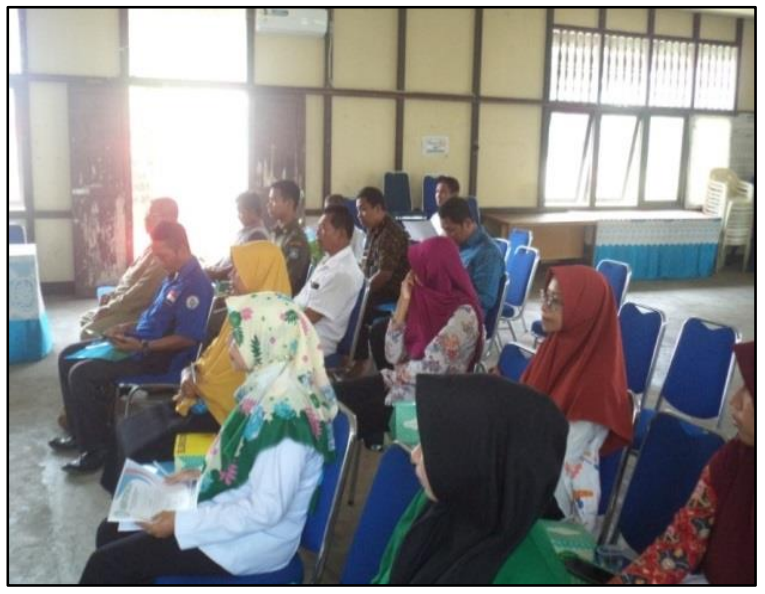

Gambar 5. Pelatihan Pustakawan di Aula Kantor Kecamatan Rasau Jaya

\section{Pelatihan Membaca dan Menulis}

Kegiatan selanjutnya adalah pelatihan membaca dan menulis. Pelatihan membaca dan menulis ini bertujuan untuk meningkatkan kemampuan membaca dan menulis anak. Selain itu, tujuan utama yaitu mensosialisasikan mengenai gerakan literasi dan pemberitahuan mengenai rumah pintar yang akan aktif dibuka untuk dimanfaatkan oleh masyarakat Rasau Jaya. Pelatihan membaca dan menulis ini digolongkan menjadi dua bagian yaitu golongan anak usia sekolah dasar dan usia sekolah menengah. Pembagian golongan ini didasarkan perkembangan kognitif antara anak usia sekolah dasar, usia menengah, dan dewasa berbeda. Pada pelatihan membaca dan menulis untuk usia sekolah dasar dilaksanakan pada 21 April 2019. Pelatihan ini dihadiri oleh 26 peserta di lingkungan Rasau Jaya, khususnya Rasau Jaya
Satu. Pelatihan membaca dan menulis ini terbatas mengenai cerpen dan puisi secara sederhana. Hasil akhir dari mereka, yaitu mampu membuat puisi mengenai kearifan lokal. Pelatihan membaca dan menulis pada anak usia sekolah menengah dilaksanakan pada 20 April 2019 dan dilanjutkan dalam pelatihan penulisan blog pada 27 April 2019. Pada pelatihan membaca dan menulis pada anak usia sekolah menengah yaitu sebanyak 25 orang.

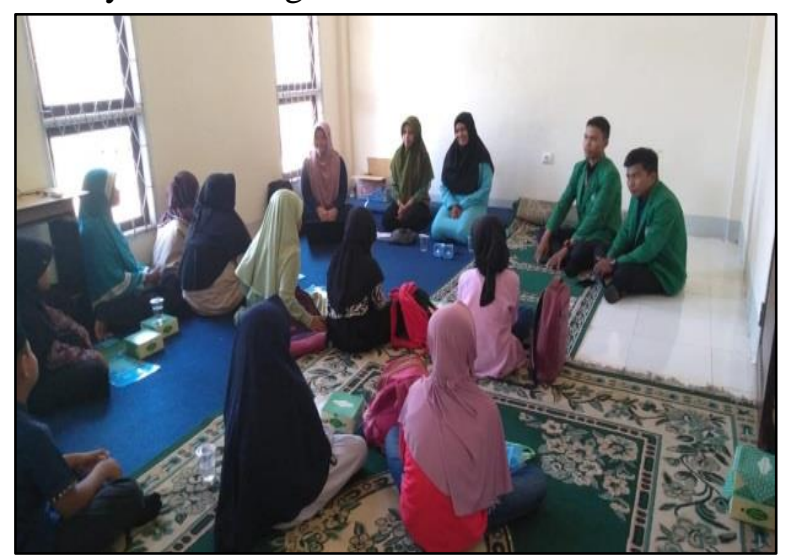

Gambar 6. Pelatihan Membaca dan Menulis Anak Usia Sekolah Dasar di Rumah Pintar Rasau Jaya

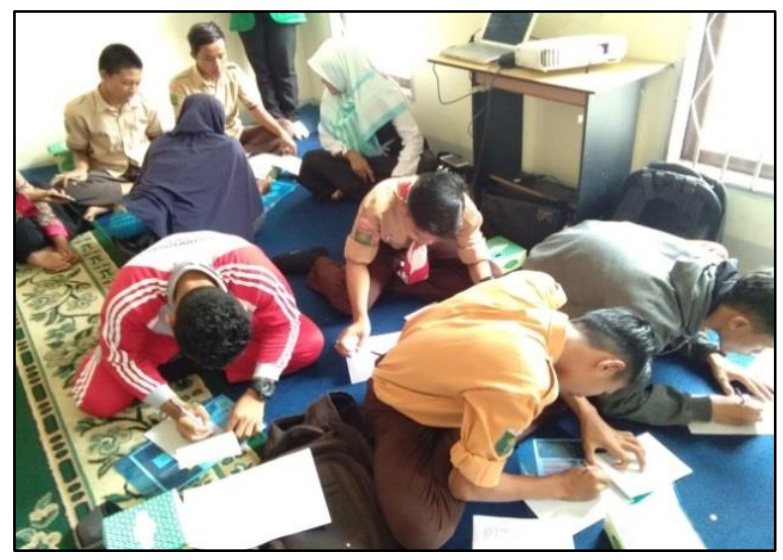

Gambar 7. Pelatihan Membaca dan Menulis Anak Usia Sekolah Menengah di Rumah Pintar Rasau Jaya

\section{Pelatihan Penulisan Blog}

Pelatihan penulisan Blog dilaksanakan pada 27 April 2019. Pelatihan penulisan blog dengan pemateri Adha Maulana, S.ST., M.T. Pelatihan penulisan blog yang di ikuti oleh 18 peserta. Peserta yang sedikit ini dikarenakan ada beberapa yang tidak memiliki laptop sebagai kendala peserta enggan mengikuti kegiatan pelatihan penulisan blog. Pelatihan penulisan blog ini diberikan dengan bekal materi mengenai pentingannya menulis, pentingnya penulisan blog, pendaftaran blog, serta publikasi ke blog. 
Peserta yang mengikuti sangat antusias, sehingga ada beberapa peserta yang langsung menanyakan kepada pemateri secara langsung. Selain materi, kegiatan ini juga dilaksanakan praktik secara langsung. Bagi yang tidak memiliki leptop, dapat menggunakan leptop yang disediakan oleh tim PKM. Pada praktik penulisan blog ini, peserta juga di dampingi oleh pemateri dan tim PKM untuk membantu berjalannya kegiatan ini. Hasil dari pelatihan penulisan blog dapat dilanjutkan oleh peserta di rumah dalam setiap harinya. Peserta pelatihan penulisan blog diberikan waktu sampai dengan 1 Agustus 2019 untuk melanjutkan penulisan berupa puisi, cerita, ataupun pengalaman yang berhubungan dengan kearifan lokal. Tindak lanjut dari kegiatan pelatihan penulisan blog ini yaitu lomba penulisan blog. Bagi peserta yang memenangkan lomba penulisan blog akan diberikan hadiah oleh Tim PKM sebagai tanda bahwa peserta tersebut ikut serta dalam menggerakkan literasi di Rasau Jaya.

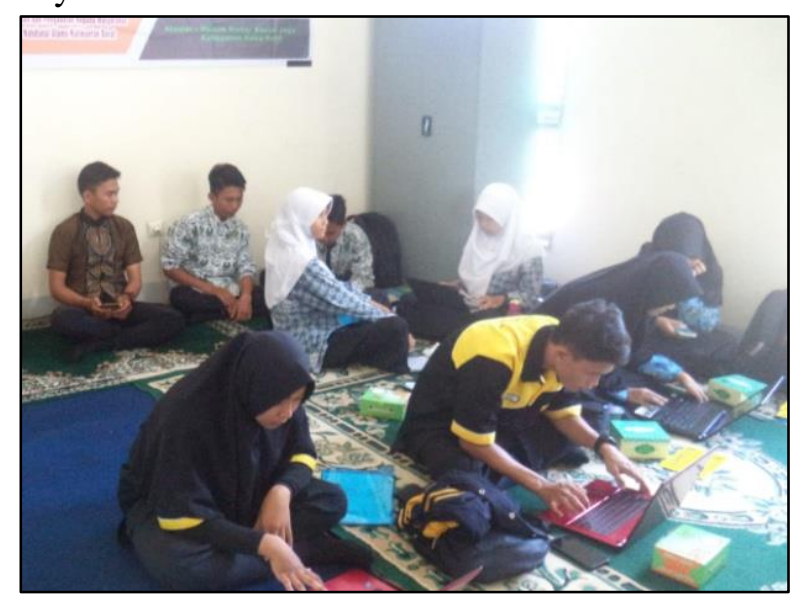

Gambar 8. Pelatihan Penulisan Blog di Rumah Pintar Rasau Jaya

\section{Penyerahan Hibah}

Penyerahan Hibah dilaksanakan oleh tim pelaksana PKM pada 17 Juli 2019 pukul 10.00 WIB. Hibah barang yang mendukung keberlanjutan anatar lain mebel, buku referensi, alat tulis kantor, dan lain sebagainya. Hibah buku terdiri dari buku cerita, novel, kebudayaa, kearifan lokal, pertanian, peternakan, perkebunan, dan lain sebagainya. Selain penyerahan hibah, penyerahan donasi buku melalui tim PKM dari balai bahasa Provinsi Kalimantan Barat dan donator lainnya. Penyerahan hibah dihadiri oleh tujuh orang antara lain tim PKM, pengelola, serta relawan pustakawan. Adapun dokumentasi sebagai berikut.

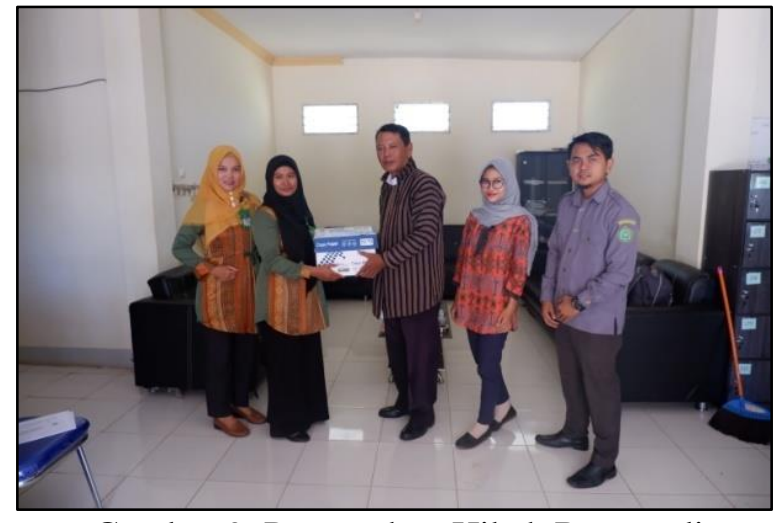

Gambar 9. Penyerahan Hibah Barang di Rumah Pintar Rasau Jaya

\section{Penataan Ruang Rumah Pintar sebagai Pusat Literasi}

Penataan ruang rumah pintar sebagai pusat literasi dilaksanakan pada 20-21 Juli 2019. Kegiatan ini antara lain membersihkan ruangan, mendesain ruangan sebagai pusat literasi, dan memberikan label pada buku yang ada di Rumah Pintar. Kegiatan ini dilaksanakan dengan tujuan agar rumah pintar ini berjalan sebagai semestinya dan juga sebagai pusat literasi di Desa Rasau Jaya. Selain itu, dengan berjalannya Rumah Pintar tersebut, masyarakat Rasau Jaya khususnya anak-anak dapat menggalakkan program literasi yang didukung dengan ketersediaan penunjang yang memadai.

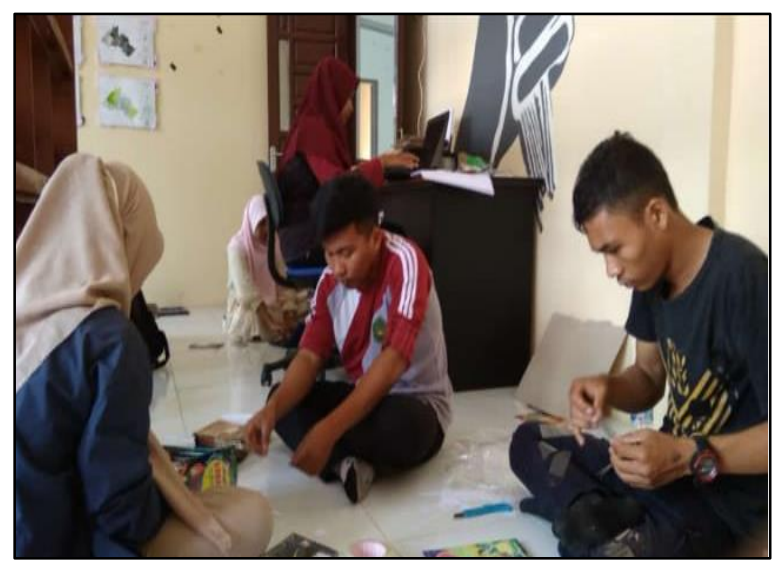

Gambar 10. Pelabelan Buku di Rumah Pintar Rasau Jaya

\section{Kegiatan Lomba}

Kegiatan lomba-lomba mengenai literasi ini diadakan pada 10 Agustus 2019 di Rumah Pintar. Kegiatan ini dilaksanakan guna mengenalkan kepada anak-anak di Rasau Jaya khususnya Desa Rasau Jaya Satu bahwa rumah pintar yang sudah lama vakum sudah dapat digunakan kembali sebagai pusat literasi. Lomba-lomba ini antara lain lomba cipta puisi dan membaca puisi untuk 
anak usia sekolah dasar. Lomba cipta puisi dan penulisan blog pada anak usia sekolah menengah. Juri untuk lomba bagi anak usia sekolah dasar yaitu Yunika Afryaningsih, M.Pd dan Dessy Setyowati, M.Pd (Tim PKM), sedangkan juri untuk lomba bagi anak usia sekolah menengah dari Tim PKM yaitu Dedek Kurniawati, M.Pd dan Exnasia Retno Palupi Handayani, M.Pd. Peserta lomba cipta puisi untuk anak usia sekolah dasar sebanyak 15 anak sedangkan untuk membaca puisi sebanyak 12 anak. Peserta lomba cipta puisi untuk anak usia sekolah menengah sebanyak 18 anak dan peserta lomba penulisan blog sebanyak 11 anak. Peserta lomba yang ditargetkan oleh Tim PKM memang tidak sesuai dengan rencana, akan tetapi tim PKM dan relawan desa akan terus berusaha menggiatkan literasi di Rumah Pintar ini.

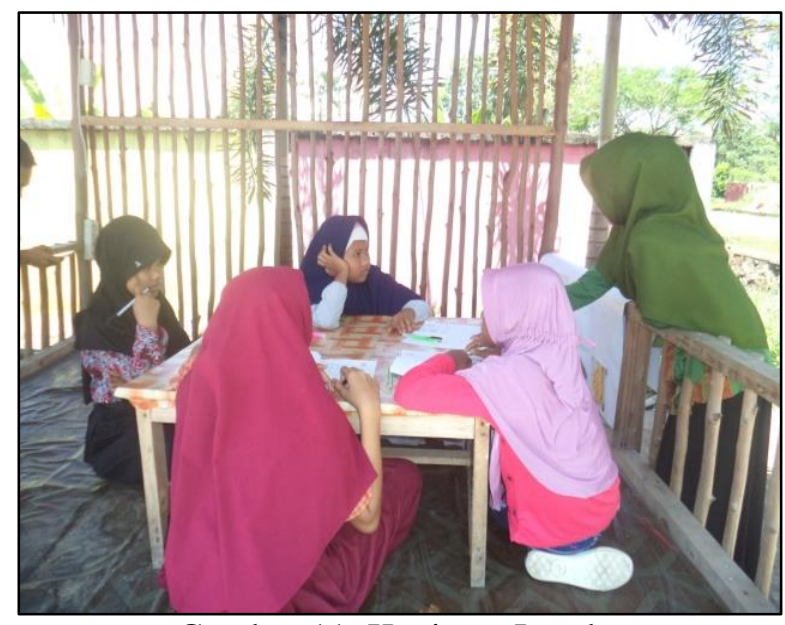

Gambar 11. Kegiatan Lomba

\section{d. Output Kegiatan}

Pada output kegiatan PKM ini antara lain tersedianya buku-buku khususnya buku yang bermuatan kearifan lokal. Buku-buku tersebut donasi dari Balai Bahasa Provinsi Kalimantan Barat, Dosen Universitas Nahdlatul Ulama Kalimantan Barat, dosen Universitas Tanjungpura, serta hibah dari Kemenristek Dikti melalui tim PKM. Harapan tim PKM, buku yang sudah tersedia dapat menumbuhkan minat baca masyarakat Rasau Jaya. Selain itu, untuk keberlangsungan kegiatan di Rumah Pintar maka dibutuhkan tim relawan desa yang mau membantu mengelola rumah pintar sebagai pusat literasi. Hasil dari sosialisasi yang bersedia sebagai tim relawan desa sebanyak 2 orang. Relawan desa ini juga sebagai penggiat literasi di Rasau Jaya. Relawan desa ini mengikuti pelatihan pustakawan yang diadakan oleh tim pkm. Pelatihan ini bertujuan agar relawan desa mampu melakukan administrasi mengenai rumah pintar. Berjalannya kegiatan PKM ini, ada beberapa tambahan relawan desa yang bergabung dalam pengelolaan rumah pintar. Luaran yang ketiga yaitu melalui pelatihan-pelatihan yang diadakan oleh tim PKM, masyarakat khususnya anak-anak paham tentang cara membaca dan menulis dengan benar. Selain itu, masyarakat juga dapat menikmati fasilitas rumah pintar untuk kegiatan literasi di Rasau Jaya. Luaran terakhir adalah penyaluran bakat. Melalui kegiatan lomba yang diadakan oleh tim pkm, masyarakat Rasau Jaya khususnya anak-anak dapat menyalurkan bakat menulis. Selain itu juga, kegiatan pelatihan penulisan blog dapat membantu masyarakat untuk menyalurkan bakat menulis lewat daring. Tersedianya wall chart di Rumah Pintar Rasau Jaya dapat menunjang penyaluran bakat masyarakat Rasau Jaya. Selain itu, tim pkm juga mendukung masyarakat untuk mengikuti perlombaan-perlombaan mengenai literasi. Kegiatan PKM ini dapat menggiatkan literasi yang ada di Rasau Jaya, khususnya di Desa Rasau Jaya Satu.

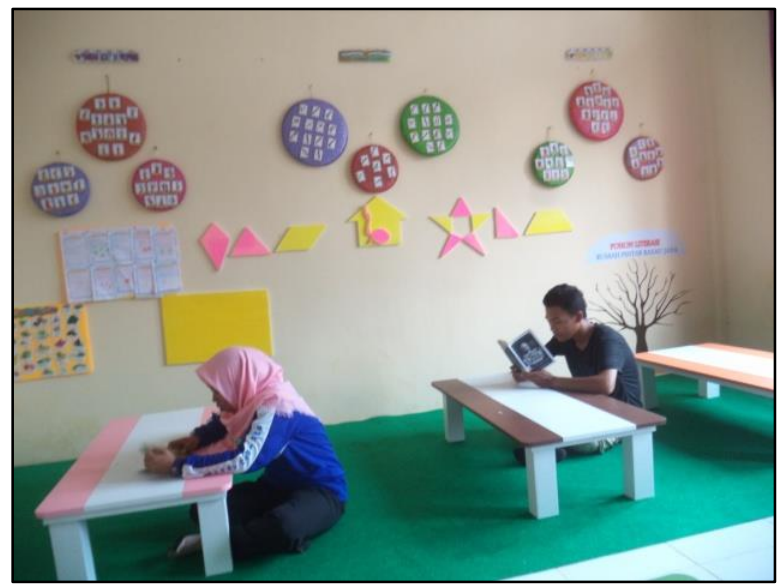

Gambar 12. Rumah Pintar

\section{KESIMPULAN}

Kegiatan PKM yang telah dilaksanakan maka dapat disimpulkan bahwa Program Kemitraan Masyarakat telah tepat sasaran. Kegiatan PKM yang dimulai dari sosialisasi, pengadaan perlengkapan rumah pintar, kegiatan pelatihan serta lomba-lomba sebagai penunjang penggiatan literasi di Rasau Jaya khususnya di Desa Rasau Jaya Satu. Masyarakat di Desa Rasau Jaya Satu juga mendukung semua kegiatan yang berkaitan dengan literasi. Keberlangsungan rumah pintar sebagai pusat literasi sangat diperlukan khususnya mengenai kebudayaan kearifan lokal. 
UCAPAN TERIMA KASIH

Tim pengabdian kepada masyarakat mengucapkan terima kasih kepada pihak yang berkontribusi dalam pendanaan kegiatan pengabdian ini yaitu Direktorat Riset dan Pengabdian kepada Masyarakat, Direktorat Jendral Penguatan Riset dan Pengembangan, Kementerian Riset, Teknologi, dan Pendidikan Tinggi.

\section{DAFTAR PUSTAKA}

Borne One TV. 2017. Miris, Rumah Pintar Miliaran Rupiah di Rasau Jaya Terbengkalai. (daring), diakses pada 20 Oktober 2018, dari www.borneonetv.com.

Undang-undang Republik Indonesia Nomor 35 tahun 2007 tentang pembentukan Kubu Raya di Provinsi Kalimantan Barat. (daring) diakses pada 22 Oktober 2018, dari www.hukumonline.com 